\title{
Immune response of calves immunized with cocktail of DNA vaccine encoding complexed outer membrane proteins from Anaplasma marginale
}

\section{Resposta imune de bezerros imunizados com um coquetel de vacina de DNA que codificam proteínas de membrana externa de Anaplasma marginale}

\author{
Adriana Letícia Mendes Coelho ${ }^{1}$; Rafael Felipe da Costa Vieira ${ }^{2}$; \\ Marcela Ribeiro Gasparini ${ }^{3}$; João Luis Garcia ${ }^{4}$; Odilon Vidotto ${ }^{4}$; \\ Marilda Carlos Vidotto ${ }^{4 *}$
}

\begin{abstract}
In the present study we evaluated a cocktail of recombinant plasmids encoding the major surface proteins (rMSP1a, rMSP1b, rMSP4, rMSP5, VirB9 and VirB10) to improve the humoral and celular immune response triggered in calves. Ten calves were divided in three groups: Four calves were inoculated with the plasmids/rMSPs (G1); 2 calves were inoculated with empty vector (G2); and 4 calves received saline (G3). Three inoculations were administered at 21-day intervals. In G1, the calves showed significant increases in total IgG level 21 days after the second inoculation, compared to the control group ( $<<0,05 \%$ ), and G1 calves remained above the cut-off value 28 days after the third inoculation $(\mathrm{p}<0,05 \%)$. The post-immunized sera from calves in G1 reacted specifically for each of the rMSPs used. Additionally, ELISA detected specific IgG for VirB9 and VirB10. In conclusion, the cocktail of recombinant plasmids induced antigen-specific seroconversion in calves. Therefore, additional testing to explore the protection induced by recombinant plasmids, alone or in conjunction with proteins previously identified as subdominant epitopes, is warranted.
\end{abstract}

Key words: Bovine anaplasmosis, DNA vaccine, cattle, immunogenicity, MSPs, VirB

\section{Resumo}

No presente estudo, avaliou-se a resposta imune humoral e celular de um coquetel de plasmídeos recombinantes que codificam as principais proteínas de superfície (rMSP1a, rMSP1b, rMSP4, rMSP5, VirB9 e virB10) em bezerros. Dez animais foram divididos em três grupos: quatro bezerros foram inoculados com os plasmídeos / rMSPs (G1); 2 bezerros foram inoculados com vetor vazio (G2), e quatro bezerros receberam salina (G3). Três inoculações foram efetuadas em intervalos de 21 dias. No G1, os bezerros apresentaram aumentos significativos nos níveis de IgG total 21 dias após a segunda inoculação, em comparação com o grupo controle ( $p<0,05 \%)$ e os bezerros do G1 permaneceram com DO acima do ponto de corte 28 dias após a terceira inoculação $(\mathrm{p}<0,05 \%)$. Os soros pós-imunes

\footnotetext{
${ }^{1}$ Discente, Programa de Pós-Graduação em Ciência Animal, UEL, Londrina, PR, Brasil. E-mail: dri_leticia@hotmail.com

${ }^{2}$ Prof. do Dept ${ }^{\circ}$ de Ciências Veterinárias, Universidade Federal da Paraíba, UFPB, Areia, PB, Brasil. E-mail: vieirarfc@gmail.com

${ }^{3}$ Discente, Programa de Pós-Graduação em Ciência Animal, UEL, Londrina, PR, Brasil. E-mail: marcelagasparini@gmail.com

${ }^{4}$ Profs. Drs. do Programa de Pós-Graduação em Ciência Animal, Dept ${ }^{\circ}$ de Medicina Veterinária Preventiva, Universidade Estadual de Londrina, UEL, Londrina, PR, Brasil. E-mail: macarlos@uel.br; vidotto@uel.br; macarlos@uel.br

* Author for correspondence
} 
dos bezerros do G1 reagiram especificamente para cada uma das rMSPs usadas. Adicionalmente, IgG específicas para VirB9 e Vir B10 foram detectadas por ELISA. Em conclusão, a associação de plasmídeos recombinantes induziu soroconversão específica nos bezerros testados. Portanto, sugerese a realização de testes adicionais para avaliar a proteção induzida pelos plasmídeos recombinantes, isoladamente ou em conjunto com as proteínas já identificadas com epítopos subdominantes.

Palavras-chave: Anaplasmose bovina, vacina de DNA, bovinos, imunogenicidade MSPs, virB

\section{Introduction}

Anaplasma marginale is an obligate intraerythrocytic rickettsial pathogen belonging to Order Rickettsiales, Family Anaplasmataceae (DUMLER et al., 2001) that causes bovine anaplasmosis (RICHEY; PALMER, 1990). Anaplasmosis is clinically characterized by fever, haemolytic anaemia, weight loss, abortion, which is an important cause of economic losses mainly in tropical and sub-tropical regions of the world (ALDERINK; DIETRICH, 1983). Vaccines against anaplasmosis have been used (VIDOTTO et al., 1998; KOCAN et al., 2003) as an alternative to control the disease; however, the commercial existing vaccines are constituted by live or dead organisms, and present limitations due to the need for cryopreservation and efficacies (KUTTLER et al., 1984).

Various major outer membranes proteins of A. marginale have been described based on the proteomic and genomic approach, and 21 proteins were identified within the outer membrane immunogen (LOPEZ et al., 2005). Major Surface Proteins (MSPs) and VirB were evaluated as potential candidates for antigens of vaccine production and diagnostic evaluations (AGNES et al., 2011).

The MSP1a and MSP1b are complexed by disulfide-bonded and no covalently associated with MSP5 (VIDOTTO et al., 1994); and this intermolecular relationships seems to be important in the induction of protective immunity (MACMILLAN et al., 2008). Vir B9 and Vir B10 are type IV secretion system (T4SS) proteins, which form channels, what facilitate secretion of molecules, and are required for intra-cellular survival. These proteins are able to stimulate CD4+ $\mathrm{T}$ cell responses in outer membrane $(\mathrm{OM})$ vaccines (LOPEZ et al., 2007; SUTTEN et al., 2010).

Immunization with DNA plasmids encoding for a determined antigen represents a promising method in vaccine research and development. Studies have demonstrated that after naked DNA immunization, the antigen is naturally processed and presented on major histocompatibility complex (MHC) class I and class II molecules, inducing a broad range of immune responses including antibody production, $\mathrm{CD}^{+} \mathrm{T}$ helper cell (Th1), and $\mathrm{CD}^{+}$cytotoxic $\mathrm{T}$ cells (CTLs) (DONNELLY et al., 1997; NAGATA et al., 2004). Furthermore, DNA vaccine demonstrated many advantages over the standard immunization procedure, such as no risk of infection, induction of a long-lived immune response, better stability than live attenuated vaccines, and low coast (DONNELLY et al., 1997).

Preliminary studies using recombinant plasmids based on $m s p 1$ a, $m s p 1$ b, $m s p 4$, and $m s p 5$ genes from A. marginale local isolated strain demonstrated good humoral and cellular immune responses in BALB/c mice (KANO et al., 2008). This work showed that the use of those plasmids as a cocktail resulted in elevated antibody titres and a strong proliferation of T lymphocytes.

The aim of this study was to construct recombinant plasmids based on Vir B9 and Vir B10 genes from A. marginale. Additionally, these plasmids were tested as a cocktail in combination with pcDNA3.1-

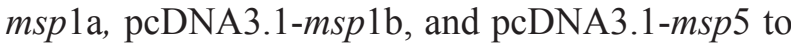
immunize calves and to evaluate the humoral and cellular immune response. 


\section{Material and Methods}

The study was approved by the Ethics Committee for Animal Experimentation and Animal Welfare at the Londrina State University, Paraná State, Brazil (CEEA number 47/05).

\section{Construction of the recombinant plasmids}

Mammalian expression vector pcDNA3.1/ TOPO (Invitrogen ${ }^{\mathrm{TM}}$ Life Technologies, Carlsbad, CA, USA) was used to construct the DNA vaccine. This vector is designed to promote constitutive expression of cloned DNA inserts in mammalian cells. The two genes encoding the antigens of interest vir $B 9$ and virB10 were amplified by PCR using primers designed based on complete gene sequence of $A$. marginale obtained by GenBank (accession number M59845 and AY714547). At position 5' of the forward primers were included CACC that is complementary sequence of vector pcDNA3.1/ TOPO (Invitrogen Life Thecnologies ${ }^{\mathrm{TM}}$ ). Reverse primers were excluded stop codon. The set of primers for vir $B 9$ and virB10 were optimizing of the parameters of PCR with the respective targets genes. PCR reagent mixture $(50 \mathrm{ml})$ consisting of 20 pmol of each primer, $200 \mathrm{mM}$ deoxynucleotide triphosphates, one unit of $P f x$ DNA polymerase (Invitrogen $^{\mathrm{TM}}$ Life Technologies, Carlsbad, CA, USA), $1.5 \mathrm{mM} \mathrm{MgSO}_{4}$. The reaction was performed in a Perkin Elmer DNA Thermal Cycler 9600 (Norwalk, CT) with the following time and temperature conditions: one step of $5 \mathrm{~min} / 94{ }^{\circ} \mathrm{C}$; followed by 35 cycles of $1 \mathrm{~min} / 94{ }^{\circ} \mathrm{C}, 1 \mathrm{~min} / 60^{\circ} \mathrm{C}$, $1 \mathrm{~min} / 68{ }^{\circ} \mathrm{C}$, and a final step of $7 \mathrm{~min} / 68^{\circ} \mathrm{C}$.

The products were analyzed by electrophoresis in a $1.5 \%$ agarose gel in TBE buffer $\mathrm{pH} 8.4(89 \mathrm{mM}$ Tris; $89 \mathrm{mM}$ boric acid; $2 \mathrm{mM}$ EDTA), ethidium bromide $(0,5 \mathrm{mg} / \mathrm{ml})$ stained, and visualized under UV light. The fragments were purified for cloning by QiAquick Gel Extraction Kit (Qiagen, Valencia, CA, USA).

The vir B9 and virB10 genes were cloned into
pcDNA3.1/TOPO as manufacturer's instructions (Invitrogen Life Thecnologies ${ }^{\mathrm{TM}}$ ). After, One Shot $^{\circledR}$ TOP10 chemically competent E. coli was transformed with $3 \mathrm{~mL}$ of the cloning reaction. The bacterial culture was spread on a Luria Bertani (LB) agar (1,0\% tryptone, 0,5\% yeast extract, 1,0\% $\mathrm{NaCl}$ and $1,5 \%$ agar, $\mathrm{pH} 7,0)$ containing ampicillin $(100 \mathrm{mg} / \mathrm{mL})$. The isolate colony was cultured in LB broth to extract plasmids using Qiaprep Spin Miniprep Kit (Qiagen Inc.).

The presence of inserts in recombinant plasmids from transformed colonies was confirmed by PCR using primers of fragment full length of genes. Furthermore, the correct in frame orientation of genes was confirmed by sequencing by Mega Bace 1000/Automated 96 Capillary DNA Sequencer (GE Healthcare, Little Chalfont, UK). Sequencing was performed to evaluate the correct in frame orientation of genes using the universal $\mathrm{T} 7$ forward primers. The quality of each sequence obtained was analyzed with Phre/Phrap/Consed Analysis Program (www.phrap.org) and the sequence identity was verified with sequences deposited in the GenBank using BLAST software (http://www.ncbi.nlm.nih. gov/BLAST).

The pcDNA3.1-msp1a, pcDNA3.1-msp1b, and pcDNA3.1-msp5 plasmids were constructs as described above in a previously study (KANO et al., 2008).

\section{Purification of recombinant Plasmids (DNA vaccine} production)

Large scales culture of TOP10 E. coli containing the recombinant plasmids pcDNA-virB9, pcDNA virB10 obtained and the plasmids constructed in a previous study, pcDNA-mspla, pcDNA-msplb, pcDNA-msp5 (KANO et al., 2008) were grown in LB broth at $37{ }^{\circ} \mathrm{C}$. The Qiagen Plasmid Mega Kit (Qiagen, Valencia, CA, USA) was used to prepare DNA and the recombinant plasmids were quantified by spectrophotometry measuring the optical density 
at $280 \mathrm{~nm}$. The empty vector pcDNA 3.1 was utilized as negative control also amplified in E. coli TOP10 strain.

\section{Production of recombinant proteins}

The recombinants VirB9 and VirB10 (rVirB9 and $\mathrm{rVirB10}$ ) were purified using Ni-NTA resin according to the manufacturer's instructions (Qiagen, Valencia, CA, USA).

\section{In vitro transfection and expression}

The recombinant plasmids were examined for antigen expression by transfection into Vero cells using lipofectamine 2000 (Invitrogen $^{\mathrm{TM}}$ Life Technologies, Carlsbad, CA, USA). After $72 \mathrm{hrs}$ of transient transfection, the cells were fixed in cover slips with cold methanol for $10 \mathrm{~min}$, acetone for 1 min, following Indirect Immunofluorescence Assay (IFA). Non-transfected Vero cells and pcDNA/ LacZ-His transfected Vero cells were used as negative and positive controls, respectively. The IFA was performed with anti-histidine diluted 1:5.000 and anti-Vir B9 and anti-VirB10 in PBS containing $2 \% \mathrm{BSA}$, and incubated for $45 \mathrm{~min}$ at $37^{\circ} \mathrm{C}$. After three washes in PBS-Tween 20, the cover slips were incubated for 45 min with FITC-anti-mouse IgG (Sigma-Aldrich Co, USA) diluted 1:900 in PBS containing $2 \%$ BSA. The IFA was examined using a fluorescence microscope with appropriate filters.

\section{Immunization}

Ten calves were randomly divided into three groups: Four calves in group G1 were inoculated intramuscularly (i.m.) with the cocktail of pcDNA3.1-msp1a, pcDNA3.1msp1b, pcDNA3.1-msp5, pcDNA3.1-VirB9, and pcDNA3.1-VirB10 plasmids $(900 \mu \mathrm{g}$ of each plasmid) plus $1 \%$ levamisole as adjuvant; two calves in group $\mathrm{G} 2$ were inoculated with the vector alone (pcDNA3.1), and four calves in group G3 were inoculated with PBS. The inoculations were administered at days 0,21 , and 42 . The animals were kept in three separated cattle pens and fed with silage and concentrate twice per day and water ad libidum. The calves were sprayed weekly with deltamethrin (Butox, Chemo) to avoid ectoparasites. At the start of the experiment, all of the calves were approximately 240 days old and were determined to be free of $A$. marginale infection by PCR (LEW et al., 2002).

\section{Monitoring of the experimental groups}

To determine the clinical parameters of the animals during the experiment, before each inoculation, the rectal temperature, and the packed cell volume (PCV) were evaluated. They were bled to obtain serum samples for ELISA.

\section{Antibody assays}

Detection of anti-A.marginale total IgG antibodies was performed by ELISA. Optimal dilutions were established using checkerboard titrations, with dilutions of sera, antigen, and conjugates. Into each well of ELISA plates (Nunc-ImmunoTM Maxisorp, Nunc, Roskilde, Denmark) were added $100 \mu \mathrm{L}$ of $A$. marginale (strain PR1) initial bodies $(10 \mathrm{mg} / \mathrm{mL})$ diluted in sodium carbonate-bicarbonate buffer $(0.05 \mathrm{M}$, $\mathrm{pH}$ 9.6). For the detection of anti-VirB9 and antiVirB10, into each well of ELISA plates (NuncImmunoTM Maxisorp, Nunc, Roskilde, Denmark) were added $100 \mathrm{uL}$ of rVirB9 $(25 \mathrm{mg} / \mathrm{mL})$ and $100 \mathrm{uL}$ of $\mathrm{rVirB} 10(50 \mathrm{mg} / \mathrm{mL})$ diluted in sodium carbonate-bicarbonate buffer $(0.05 \mathrm{M}, \mathrm{pH}$ 9.6). After overnight incubation at $4{ }^{\circ} \mathrm{C}$, the plates were washed with PBS containing $0.05 \%$ Tween-20 (GE Healthcare, USA) (PBS-Tween $\mathrm{pH}$ 7.4). The plates were blocked for 1 hour at $37^{\circ} \mathrm{C}$ using $200 \mu \mathrm{L}$ of $8 \%$ non-fat dry milk and were washed five times with PSB-Tween ( $\mathrm{pH}$ 7.4) in an automatic microplate washer (Bio-Rad ImmunoWash, California, USA). 
For anti-A.marginale total $\mathrm{IgG}$, serum samples were diluted (1:400) in PBS-Tween ( $\mathrm{pH} 7.4)$ plus $5 \%$ rabbit normal sera, and $100 \mathrm{~mL}$ were added in duplicate to each well and then incubated at $37{ }^{\circ} \mathrm{C}$ for 90 minutes. For anti-VirB9 and anti-VirB10 antibodies, serum samples were diluted $(1: 100)$ in PBS-Tween ( $\mathrm{pH}$ 7.4) plus 1\% non-fat dry milk, and $100 \mathrm{~mL}$ was added in duplicate to each well and incubated at $37^{\circ} \mathrm{C}$ for 1 hour. Rabbit antibovine IgG alkaline phosphate conjugate (Sigma Aldrich Inc., St. Louis, MO, USA), diluted 1:20.000 (total IgG) and 1:8,000 (anti-VirB9 and anti-VirB10) in PBS-Tween (pH 7.4), was added $(100 \mu \mathrm{L})$ to each well and incubated at 37 ${ }^{\circ} \mathrm{C}$ for 90 minutes. The plates were then washed five times with PBS-Tween ( $\mathrm{pH} 7.4)$ and $100 \mu \mathrm{L}$ of o-phenylenediamine (OPD) (Sigma-Aldrich) solution was added in a concentration of $0.4 \mathrm{mg} /$ $\mathrm{mL}$ using appropriate diluents with hydrogen peroxide. The reaction was interrupted by adding $50 \mu \mathrm{L}$ of $1 \mathrm{~N} \mathrm{HCl}$, and the OD reading at $490 \mathrm{~nm}$ was obtained using an ELISA reader (iMarkTM Microplate Absorbance Reader, Bio-Rad Inc., Hercules, CA, USA).

The absorbance values were estimated, and the OD values were calculated as previously described (GARCIA et al., 2006). A serum was considered to be positive when OD sample $>$ OD mean from negative control sera $(n=10) \pm 3$ SDs (standard deviation) from the negative control.

\section{Statistical analysis}

The data were first tested for normality and homogeneity of variances, and if they did not present normal distribution, they were analyzed by nonparametric statistical tests. Differences between groups at each moment were verified by the Kruskal-Wallis test, followed by Dunn's multiple comparison test. Statistical analysis was considered significant when $\mathrm{p}<0.05$. Data were analyzed using BioEstat software, version 5.0 (AYRES et al., 2007).

\section{Results}

\section{Recombinant plasmids}

The sequence confirmed the correct insertion of VirB9 and VirB10 genes of vector plasmidial pcDNA3.1/TOPO and demonstred identity of sequence of VirB9 (EU497963) and VirB10 (NC004842) genes of A.marginale using the software BLAST (http://www.ncbi.nim.nih.gov/BLAST).

Cells transfected with recombinant plasmids (pcDNA-VirB9 and pcDNA-VirB10) expressed specific proteins by IFA. Non-transfected Vero cells did not express any immunoreactive protein with anti-histidine, IgY anti-VirB9 and IgY antiVirB10. In the positive control, the Vero cells transfected with pcDNA-lacZ-His presented fluorescence with anti-histidine monoclonal antibody. The fluorescence was verified in Vero cells transfected with pcDA-virB9 and with pcDNA-virB10 (Figure 1).

\section{Seroconversion}

The data for anti- $A$. marginale total $\mathrm{IgG}$ obtained by ELISA are shown in Figure 2. Calves from G1 showed a significant increase in total IgG levels 21 days after the second inoculation, compared to the control group ( $\mathrm{p}<0,05 \%$ ), and the levels remained above the cut-off value 28 days after the third inoculation $(p<0,05 \%)$. Animals from G2 and G3 presented median OD values for total IgG below the cut-off value until 28 days after the third inoculation (Figure 2). The data for antiVirB9 and anti-VirB10 IgG antibodies obtained by ELISA are shown in Figure 3. Calves from G1 showed a significant increase in anti-VirB9 antibody levels 21 days after the first inoculation, compared to the control group $(p=0.07)$, and the levels remained above the cut-off value 28 days after the third inoculation $(p=0.02)$. Animals from G2 and G3 presented median OD values for antiVirB9 IgG antibodies below the cut-off value until 28 days after the third inoculation (Figure 3). For 
anti-VirB10, calves from G1 presented humoral remained above the cut-off value 28 days after the responses 21 days after the second inoculation, third inoculation $(\mathrm{p}=0.28)$. Calves from G2 also compared to the control group $(\mathrm{p}=0.07)$, and presented humoral responses (Figure 3 ).

Figure 1. Immunofluorescence of Vero cells transfected with DNA vaccine encoding Anaplasma marginale rMSP1a, rMSP1b, rMSP5 e VirB9 antigens, using monoclonal antibodies (400×). (A) Non-transfected Vero cells; (B) pcDNA3.1lacZ Vero cells transfected using anti-histidine monoclonal antibody (positive control); (C) pcDNA3.1-mspla using ANA22B1 monoclonal antibody; (D) pcDNA-msp $1 b^{2}$ using anti-histidine monoclonal antibody; (E) pcDNA-msp5 using ANAF16C1 monoclonal antibody and (F) pcDNA3.1-Vir B9 using anti-histidine monoclonal antibody.

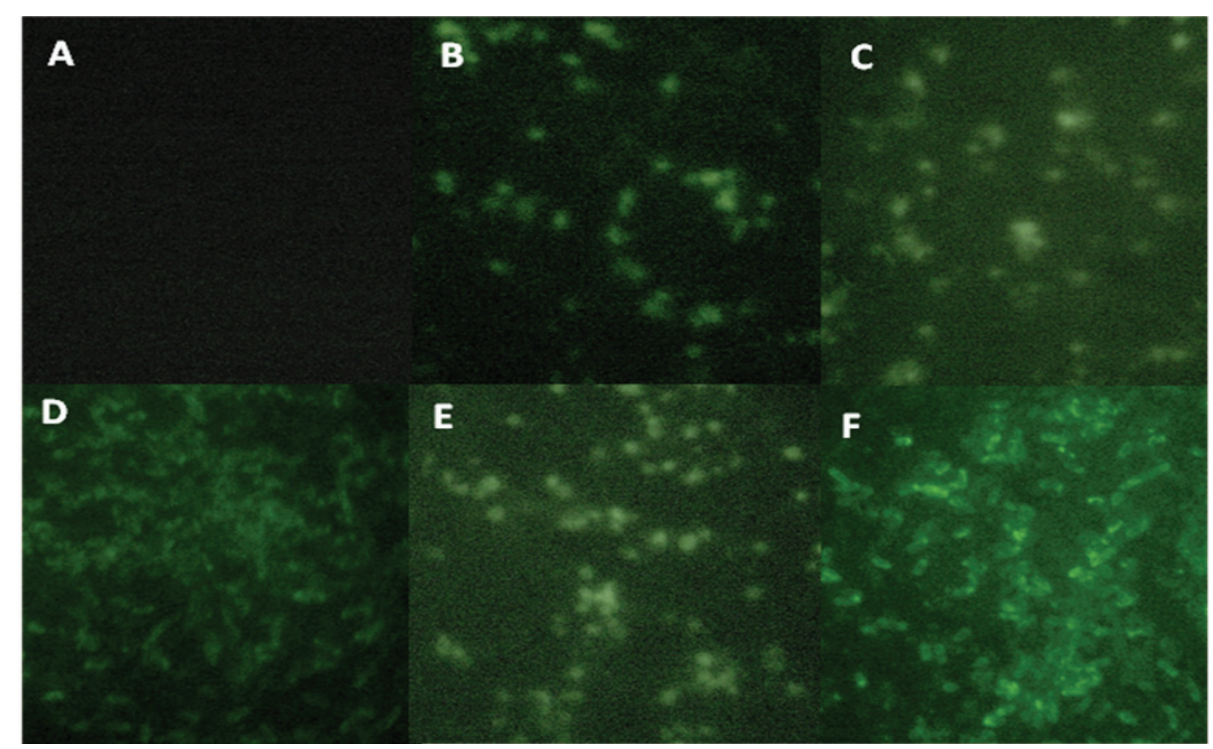

Source: Elaboration by the authors.

Figure 2. Median optical density (OD) values of total IgG obtained by indirect ELISA from calf groups submitted to the different inoculation protocols, DO - Day of the first dose of inoculation; D21 - 21 days after the first inoculation; D42 - 21 days after the second inoculation; D70 - 28 days after the third inoculation.

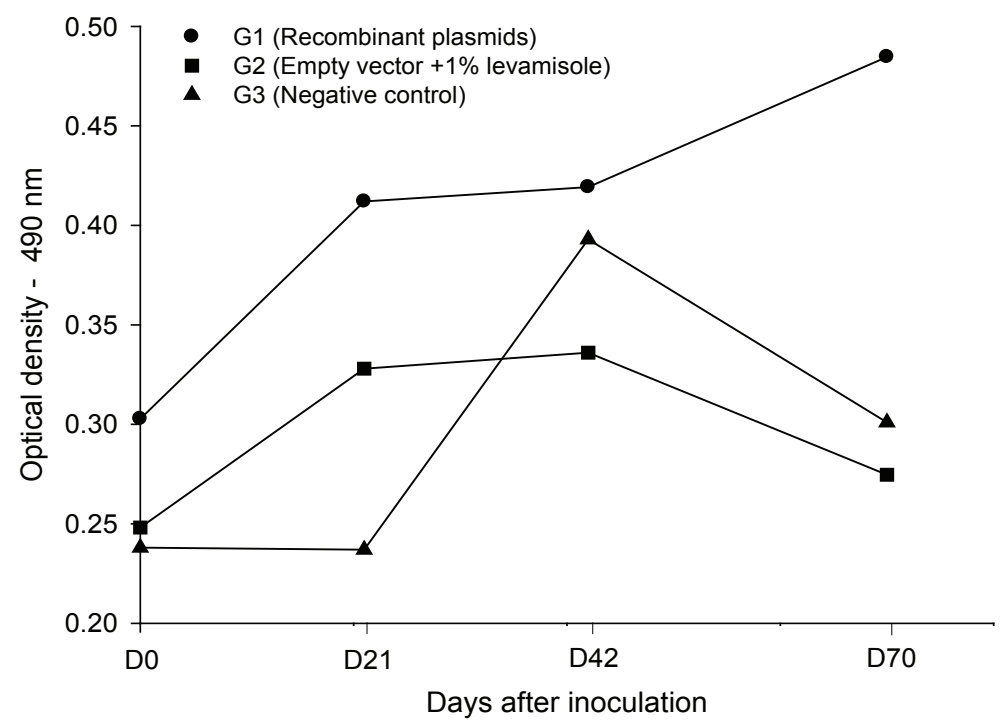

Source: Elaboration by the authors. 
Figure 3. Median optical density (OD) values of IgG anti-VirB9 (solid line) and IgG anti-VirB10 (dash line) obtained by indirect ELISA from calf groups submitted to the different inoculation protocols, DO - Day of the first inoculation; D21 - 21 days after the first inoculation; D42 - 21 days after the second inoculation; D70 - 28 days after the third inoculation.

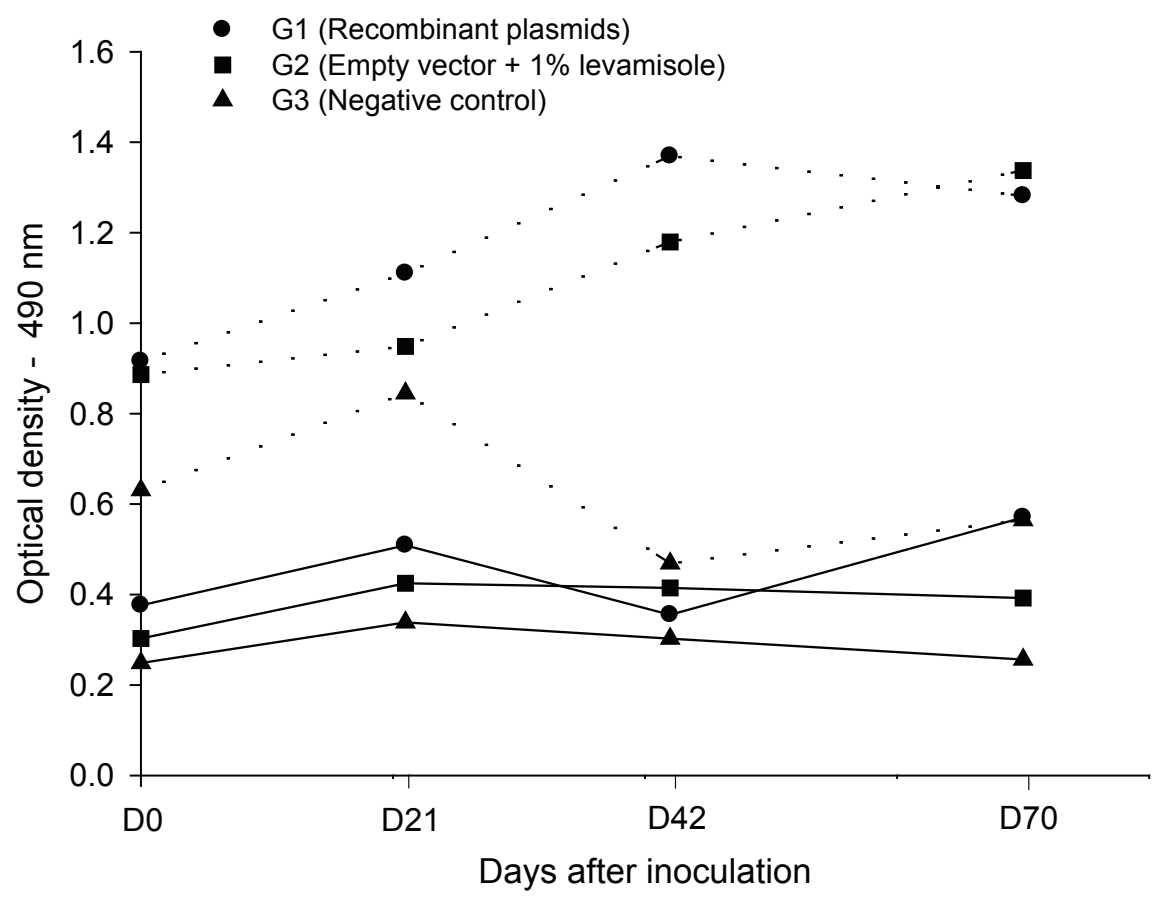

Source: Elaboration by the authors.

\section{Celular response}

The mean lymphocyte stimulation index (SI) of the animals of the $\mathrm{G} 1$ was $\mathrm{x} 5=3,2, \mathrm{x} 10=2,0$, x $20=1.9$ at concentrations of 5, 10 and $20 \mu \mathrm{g} /$ $\mathrm{mL}$ of a cocktail of rMSP1a, rMSP1b, rMSP5 e
VirB9 proteins, respectively. The calves from G1, immunized with a cocktail of recombinant plasmids, presented significant lymphocyte proliferation at concentration of $10 \mu \mathrm{g} / \mathrm{mL}(\mathrm{SI} \geq 2)$ (Figure 4). 
Figure 4. Lymphocytes proliferation of the calves immunized with a cocktail of DNA vaccine encoding complexed outer membrane proteins from Anaplasma marginale. Mean lymphocyte stimulation index (SI) of the animals with a cocktail of the recombinant proteins rMSP1a, rMSP1b, rMSP5 e VirB9 $(5,10$ e 20 $\mu \mathrm{g} / \mathrm{mL})$ and the positive control Phytohemaglutin-A(PHA-M). A: G1 - immunized with a cocktail of recombinant plasmids with significant lymphocyte proliferation at concentration of $10 \mu \mathrm{g} / \mathrm{mL}(\mathrm{SI} \geq 2)$. B and $\mathrm{C}$ : $\mathrm{G} 2$ (vector pcDNA3.1/TOPO) and G3 (negative control - saline) without significant growing ( $\mathrm{SI}>2)$.
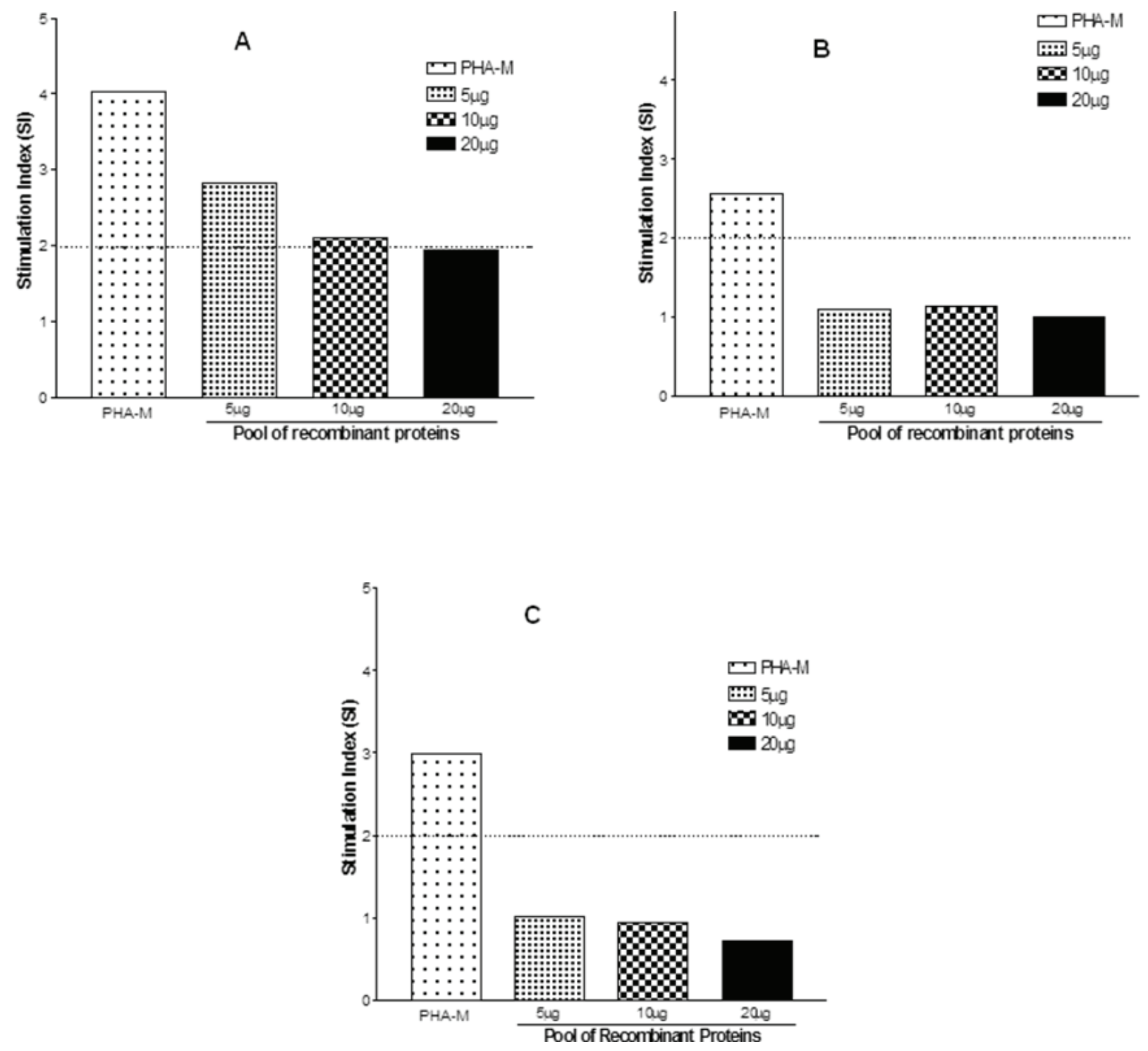

Source: Elaboration by the authors.

\section{Discussion}

The vaccination with DNA is one of the most promising immunization techniques against a pathogens variety, for which the conventional methods have not been efficient. DNA vaccines are capable to induce immune humoral and cellular response, directed to lymphocytes CD4+ and
CD8+, without the necessity of live microorganisms (KANO; VIDOTTO; VIDOTTO, 2007; NAGATA et al., 2004). The immunity depends on several factors such as the selection of the target gene, construction of the expression vector, frequency and via of administration of the vaccine, amount of DNA, location of the antigen codified by the 
plasmid and age, health and species of vaccinated animals (KANO; VIDOTTO; VIDOTTO, 2007). We constructed recombinant plasmids encoding complexed outer membrane proteins (OMPs), the MSP1a, MSP1b, MSP5, VirB9 and VirB10 of PR1 A. marginale strain.

VirB9 and VirB10 of A. marginale strain, as others T4SS proteins, offer the potential for use as a vaccine target. These proteins have the predicted localization to the outer membrane of $A$. marginale and are required for invasion and intracellular survival of bacterial pathogen (SUTTEN et al., 2010). A. marginale T4SS proteins VirB9 and VirB 10 are recognized by both IgG and CD4_T cells from cattle immunized with the protective outer membrane vaccine (Lopez, 2007). Also, antibody specific for VirB9 and VirB10 was detected in cattle experimentally or naturally infected with $A$. marginale in Brazil (Araujo et al., 2008, Vidotto et al., 2008). The VirB9, VirB10, MSP1a, MSP1b, and MSP5 of $A$. marginale were successfully detected in Vero cells transfected with pcDA-virB9 and with pcDNA-virB10, pcDNA-mspl $\alpha, \operatorname{pcDNA}-m s p 1 \beta$, and pcDNA-msp5, respectively, as demonstrated by IFA using anti-his and specific antibodies; while the administration of the 5 recombinant plasmids elicited specific antibody response against VirB9, VirB10, MSP1a, MSP1b and MSP5 in calves. Previous studies also related that $A$. marginale DNA vaccines induced immune responses in BALB/c mice immunized with a DNA vaccine encoding MSP1a (ARULKANTHAN et al., 1999). These authors immunized calves with $\mathrm{pVCL} / m s p 1 \alpha$ and detected only IgG1 antibodies in the sera of animals following DNA vaccination, although sera from bovine immunized with initial bodies of A. marginale demonstrated both $\operatorname{IgG} 1$ and $\mathrm{IgG} 2$ antibodies.

The few studies relative to the control of anaplasmosis using DNA vaccination are based either on the mspl $\alpha$ and have demonstrated partial protection for virulent challenge with $A$. marginale strain MSP1a (ARULKANTHAN et al., 1999). Brown et al. (2001) reported high titers of total IgG in cattle and mice immunized with complex MSP1a. Andrade et al. (2004) induced response in cattle vaccinated with recombinant plasmid MSP1b. In the present work, the calves immunized with $A$. marginale DNA vaccines (pcDA-virB9, pcDNAvirB10, pcDNA-mspla, pcDNA-mspl $\beta$, and pcDNA-msp5) presented significant lymphocyte proliferation at concentration of $10 \mu \mathrm{g} / \mathrm{mL}(\mathrm{SI} \geq 2)$ (Figure 4).

Incorporation of multiepitopes in DNA immunization consists of a new method to increase immunogenicity and protection of the vaccinated animal as compared to single vaccine epitopes (MORRIS et al., 2000). The OMPs of bacterial pathogens often protect against disease, and this protection cannot be fully reproduced by using individual OMPs. The naturally occurring intermolecular interactions between OMPs influence the immune response and may lead to more effective vaccine design. Kano et al. (2008) found high levels of antibodies and intense proliferation of lymphocytes after immunization of $\mathrm{BALB} / \mathrm{c}$ mice with recombinant plasmids (pcDNA/MSP1a, pcDNA/MSP1b and pcDNA/ MSP5). In this work we demonstrated the capacity of the recombinant plasmids to express complexed OMPs of $A$. marginale and the immune response of calves immunized with these recombinant plasmids.

In conclusion, two doses cocktail of DNA vaccine encoding complexed outer membrane proteins from A. marginale were sufficient to stimulate the immune humoral and cellular responses of the vaccinated calves. Additionally, the calves showed specific response for each recombinant plasmid incorporated to the vaccine. Therefore, additional testing to explore the protection induced by recombinant plasmids, alone or in conjunction with proteins previously identified as subdominant epitopes, is warranted. 


\section{References}

ALDERINK, F. J.; DIETRICH, R. A. Economic and epidemiological implications of anaplasmosis in Texas beef cattle herds. The Texas $A \& M$ University System, Texas, B-1426, p. 1-16, 1983.

ANDRADE, G. M.; MACHADO, R. Z.; VIDOTTO, O.; VIDOTTO, M. C. Immunization of bovines using a DNA vaccines (pcDNA3.1/MSP1b) prepared from the Jaboticabal strain of Anaplasma marginale. Annals of the New York Academy of Sciences, New York, v. 1026, p. 257-266, 2004.

ARAUJO, F. R.; COSTA, C. M., C. A.; RAMOS, T. A.; FARIAS, I. I.; SOUZA, E. S.; MELO, C.; ELISEI, G. M.; ROSINHA, C. O.; SOARES, S. P., FRAGOSO, A. H. IgG and IgG2 antibodies from cattle naturally infected with Anaplasma marginale recognize the recombinant vaccine candidate antigens VirB9, VirB10, and elongation factorTu. Memorias do Instituto Oswaldo Cruz, Rio de Janeiro, v. 103, n. 103, p. 186-190, 2008.

ARULKANTHAN, A.; BROWN, W.; MCGUIRE, T. C.; KNOWLES, D. P. Biased Immunoglobulin isotype response induced in cattle with DNA expressing mspla of Anaplasma marginale. Infection and Immunity, Washington DC, v. 67, n. 7, p. 3481-3487, 1999.

AYRES, M.; AYRES, J. R. M.; AYRES, D. L.; SANTOS, A. S. Bioestat 5.0. Aplicações estatísticas das áreas das ciências biológicas e médicas. Belém: Sociedade Civil Mamiraua, 2007. 364 p.

BROWN, W. C.; GUY, H. P.; HARRIS, A. L.; TRAVIS, C. M. CD4_ T Lymphocytes from calves immunized with Anaplasma marginale major surface protein 1 (MSP1), a heteromeric complex of MSP1a and MSP1b, preferentially recognize the MSP1a carboxyl terminus that is conserved among strains. Infection and Immunity, v. 69, n. 11, p. 6853-6862, 2001.

DONNELLY, J. J.; ULMER, J. F.; SHIVER, J. W.; LIU, M. A. DNA vaccines. Annual Review of Immunology, Palo Alto, California, v. 15, p. 617-648, 1997.

DUMLER, J. S.; BARBET, A. F.; BEKKER, C. P. J.; DASCH, G. A.; PALMER, G. H.; RAY, S. T.; RIKIHISA, Y.; RURANGIRWA, F. R. Reorganization of genera in families Rickettsaceae and Anaplasmataceae in the order Rickettsiales $>$ unification os some species of Ehrlichia with Anaplasma, Cowdria with Ehrlichia with Neorickettsia, descriptions of six new species combinations and designation of Ehrlichia phagocytophila. International of Systematic and Evolutionary Microbiology, Spencers Wood, v. 51, p. 2145-2165, 2001.

GARCIA, J. L.; NAVARRO, I. T.; VIDOTTO, O.; GENNARI, S. L.; MACHADO, R. Z.; DA LUZ
PEREIRA, A. B.; SINHORINI, I. L. Toxoplasma gondii: Comparison of a rhoptry-ELISA with IFAT and MAT for antibody detection in sera of experimentally infected pigs. Experimental Parasitology. v. 113, n.2, p. 100-105, 2006.

KANO, F. S.; TAMEKUNI, K.; COELHO, A. L. M.; GARCIA, J. L.; VIDOTTO, O.; NAKAGAWA, E. I.; VIDOTTO, M. C. Induced immuneresponse of DNA vaccine encoding as association MSP1a, MSP1b, and MSP5 antigens of Anaplasma marginale. Vaccine, Kidlinton, v. 26, n. 27-28, p. 3522-3527, 2008.

KANO, F. S.; VIDOTTO, O.; VIDOTTO, M. C. DNA vaccines: general concerns and its applications in human and Veterinary Medicine Semina: Ciências Agrárias, Londrina, v. 28, n. 3, p. 349-354, 2007.

KOCAN, K. M.; de la FUENTE, J.; GUGLIEMONE, A. A.; MELÉNDEZ, R. D. Antigens and alternatives for control of Anaplasma marginale infection in catle. Clinical Microbiology Reviews, Washington DC, v. 16, n. 4, p. 694-712, 2003.

KUTTLER, K. L.; ZAUGG J. L.; JOHNSON, L. W. Serologic and clinical responses of premunized, vaccinated and previously infected cattle to challenge exposure by two different Anaplasma marginale. American Journal Veterinary Research, v. 45, p. 2233, 1984.

LEW, A. E.; BOCK, R. E.; MINCHIN, C. M.; MASAKA, $\mathrm{S}$. A msp1a polymerase chain reaction assay for specific detection and differentiation of Anaplasma marginale isolates. Veterinary Microbiology, v. 86, p. 325-335, 2002.

LOPEZ, J.E.; SIEMS, W.F.; PALMER, G.H.;BRAYTON, K. A.; MCGUIRE, T. C.; NORIMINE, J.; BROWN, W. C. Identification of novel antigenic proteins in a complex Anaplasma marginale outer membrane immunogen by mass spectrometry and genomic mapping. Infection and Immunity, Washington DC, v.73, p. 8109-8118, 2005.

LOPEZ, J. E.; BEARE, P. A.; HEINZEN, R. A.; NORIMINE, J.; LAHMERS, K. K.; PALMER, G. H.; BROWN, W. C. High-throughput identification of T-lymphocyte antigens from Anaplasma marginale expressed using in vitro transcription and translation. Journal of Immunological Methods, v. 332, p. 129-141, 2008.

LOPEZ, J. E.; PALMER, G. H.; BRAYTON, K. A.; DARK, M. J.; LEACH, S. E.; BROWN, W. C. Immunogenicity of Anaplasma marginale type IV secretion system proteins in a protective outer membrane vaccine. Infection and Immunity, Washington, v. 75, n. 5, p. 2333-2342, 2007. 
MACMILLAN, H.; NORIMINE, J.; BRAYTON, K. A.; PALMER, G. H.; BROWN, W. C. Physical linkage of naturally complexed bacterial outer membrane proteins enhances immunogenicity. Infection and Immunity, Washington DC, v. 76, p. 1223-1229, 2008.

MORRIS, S.; KELlEY, C.; HOWARD, A.; LI, Z.; COLLINS, F. The immunogenicity of single and combination DNA vaccines against tuberculosis. Vaccine, Kidlinton, v. 18, n. 20, p. 2155-2163, 2000.

NAGATA, T.; AOSHI, T.; UCHIMA, M.; SUZUKI, M.; KOIDE, Y. Cytotoxic T-lymphocyte, and helper-Tlymphocyte-oriented DNA vaccination. DNA and Cell Biology, New York, v. 23, n. 2, p. 93-106, 2004.

RICHEY, E. J.; PALMER, G. H. Bovine anaplasmosis. Continuing Education Article, v. 10, n. 12, p. 16611668, 1990.

SUTTEN, E. L.; NORIMINE, J.; BEARE, P. A.; HEINZEN, R. A.; LOPEZ, J. E.; MORSE, K.; BRAYTON, K. A.; GILlESPIE, J. J.; BROWN, W. C. Anaplasma marginale Type IV secretion system proteins VirB2, VirB7, VirB11, and VirD4 Are immunogenic components of a protective bacterial membrane vaccine. Infection and Immunity, Washington DC, v. 78, n. 3, p. 1314-1325, 2010.
VIDOTTO, O.; BARBOSA, C. S.; ANDRADE, G. M.; DA ROCHA, M. A.; SILVA, S. S. Evaluation of a trivalent attenueted vaccine against babesiosis and anaplasmosis in Brazil. Annals of the New York Academy of Sicences, New York, v. 849, p. 420-423, 1998.

VIDOTTO, M. C.; MCGUIRE, T. C.; MCELWAIN, T. F.; PALMER, H. G.; KNOWLES, D. P. Intermolecular relationships of major surface proteins of Anaplasma marginale. Infection and Immunity, Washington DC, v. 62, p. 2940-2946, 1994.

VIDOTTO, M. C.; VENÂNCIO, E. J.; VIDOTTO, O. Cloning, sequencing, and antigenic characterization of rVirB9 of Anaplasma marginale isolated from Parana State, Brazil. Genetics and Molecular Research, Ribeirão Preto, v. 7, p. 460-466, 2008. 
